\title{
New Plant Records for Saskatchewan
}

\author{
by John H. Hudson, Saskatoon
}

Some new or little known plants turned up by me the last two summers are worth mentioning. In all cases duplicaites have been deposited at the herbarium of the Dominion Department of Agriculture, Ottawa.

Polygonatum canaliculatum (Muhl) Pursh. Collected as \#2066 on July 1, 1959 , in hardwood forest in the Souris River valley on NE $1 / 4-11-2-7-W 2$, just south of Estevan. This denizen of the eastern hardwood foresits looks much like Star-flowered Solomon's-seal (Smilacina stellata) but in height and leaf-widith is twice as large. The greenish-white bell-shaped flowers are hidden underneath the broad leaves in long-sitalked clusters of 2-4.

Sitanion hystrix (Nuiti). J. G. Smith. Squirrel Tail. Collected as \#2078 on August 24, 1959, on a dry, bare southfacing shaly slope on NW $1 / 4-21-11$ 29-W3, in the Box Elder Creek country south of Hatton. This has been reported only from Val Marie, but has likely been passed over else- where because of its marked likeness to Wild Barley (Hordeum jubatum). Munroa squarrosa (Nutt.) Torr. False Buffalo Grass. Collected as \#2082 on a dry, sandy roadside on SE $1 / 4-34-12-29-W 3$ on August 25, 1959 , on old Highway \#1 a mile and a half west of Hatton. There were fair quantities of the plant present. This was previously reported for Saskatchewan from the river valley near Saskatchewan Landing by Tisdale and Budd in the Canadian Field Naturalist 62, 174, 1948.

Eragrostis cilianensis (All) Link. Stinkgrass. Collected as \#2088 in Estevan, September 17, 1960. It was growing as a rather rare street weed on dry city boulevards; my specimens came from the corner of 6 th St. and 4th Ave. This has not been reported before from Saskatchewan as far as I know. However it is a common introduced weed in North Dakota according to Stevens (Handbook of North Dakota Plants), and has shown up in Manitoba, so an appearance at Estevan is not unexpected.

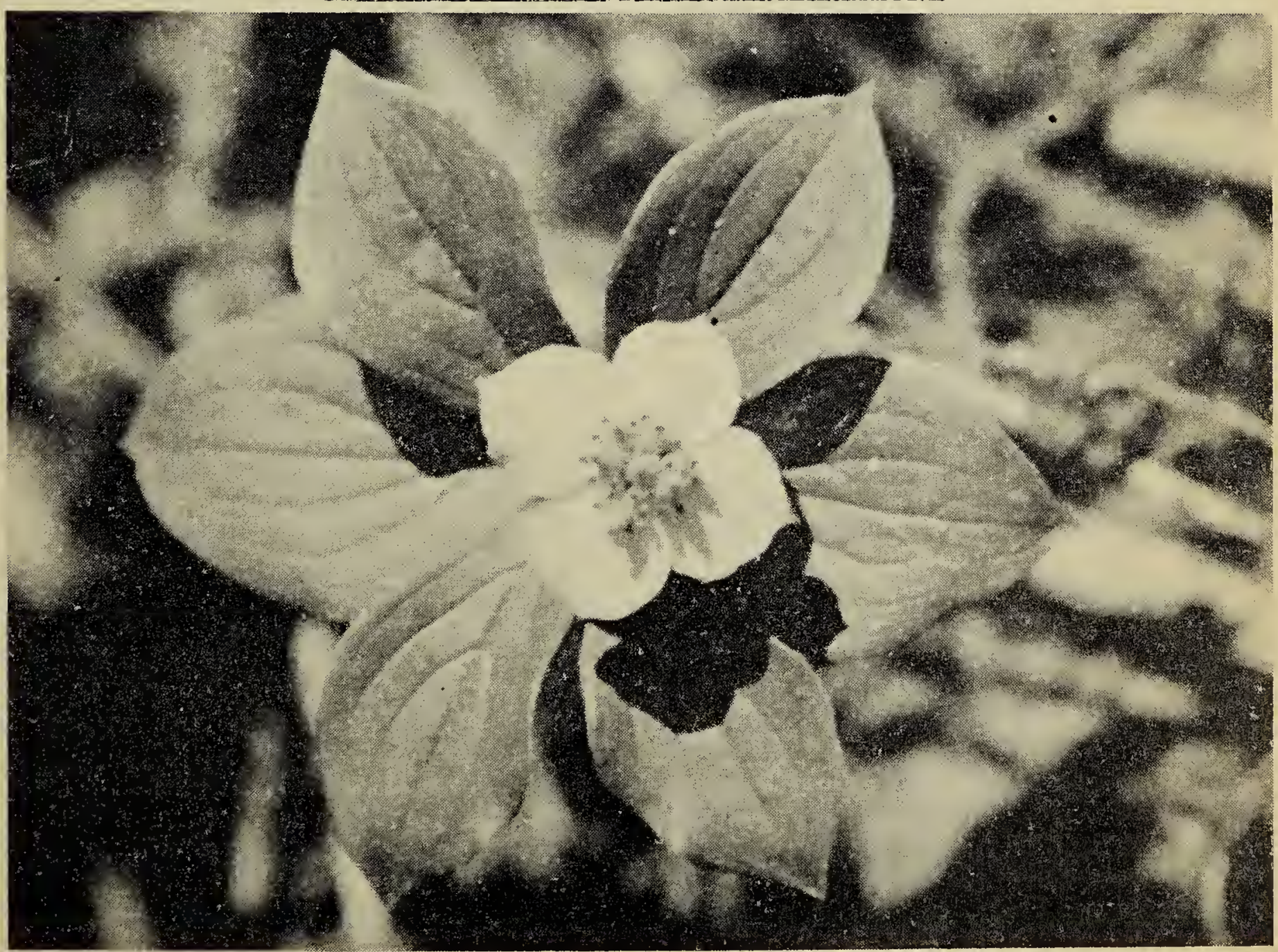

Photo by M. A. Welsh 